\title{
ANALYSIS OF PAIN RELIEF IN EPISIOTOMY WOUND WITH INFRARED RADIATION VERSUS ROUTINE PERINATAL CARE AMONG POSTNATAL MOTHERS IN TAMILNADU, MARCH 2017
}

\author{
Mariappan Gomathi', Thanga Poosamy Jaya Kumar², Periyaswamy Jayaseeli ${ }^{3}$ \\ ${ }^{1}$ Associate Professor, Government Vellore Medical College Hospital, Adukkamparai, Vellore. \\ ${ }^{2}$ Associate Professor, Madras Medical College Hospital, Chennai. \\ ${ }^{3}$ Assistant Surgeon, Madras Medical College Hospital, Chennai.
}

ABSTRACT

\section{BACKGROUND}

Postpartum period is a crucial period of caring for mothers, especially those who had undergone episiotomy. Episiotomy is the surgical incision made in the perineum during the second stage of labour. Episiotomy is very painful during puerperal period. Trauma of perineum can cause considerable distress and discomfort for many women following childbirth that can affect the mental, social and physical wellbeing of the woman. Some have postpartum pain and discomfort, which may persist beyond as chronic pain and painful sex. In addition, infection, wound breakdown, urinary and faecal incontinence and other spectrum of adverse effect of treatment of trauma in perineum can make the postpartum period very unpleasant. While factors like suture techniques, operator skills and suture materials may affect pain and wound healing, different strategies have been used in order to promote perineum wound healing.

The aim of this study is to evaluate the effectiveness of infrared radiation lamp therapy for pain relief of episiotomy wound among postnatal mothers by comparing experimental and controlled group score.

\section{MATERIALS AND METHODS}

All patients aged 18 to 34 years were taken into the study after taking written consent, infrared radiation therapy was given to the experimental group for three days and routine perinatal care given to the control group.

Study Design- Non-randomised, controlled trial.

Inclusion Criteria- All postnatal mothers with episiotomy wound, first 3 days of postnatal period, right mediolateral and left mediolateral episiotomy, forceps or vacuum delivery.

Exclusion Criteria- Postnatal mothers with Defective sensation in perineal region, Severe anaemia, Unconscious postnatal mothers, Psychiatric illness, Postnatal mothers with Heart disease.

\section{RESULT}

Episiotomy wound pain relief was observed in experimental group as compared to control group.

\section{CONCLUSION}

Infrared lamp radiation therapy is an effective modality of treatment for pain relief of episiotomy wound.

\section{KEYWORDS}

Infrared Radiation, Episiotomy Wound, Postnatal Mothers.

HOW TO CITE THIS ARTICLE: Gomathi M, Kumar TPJ, Jayaseeli P. Analysis of pain relief in episiotomy wound with infrared radiation versus routine perinatal care among postnatal mothers in Tamilnadu, March 2017. J. Evolution Med. Dent. Sci. 2018;7(01):107-110, DOI: $10.14260 /$ jemds/2018/23

\section{BACKGROUND}

Infrared is classified as superficial heat, ${ }^{6}$ although it is an electromagnetic energy modality rather than a conduction energy modality, depth of penetration of heat is $1 \mathrm{~cm}$. IRR is a dry heat modality compared with other types of superficial heat therapy. Dry heat from an IRR tends to elevate superficial temperatures more than moist heat. ${ }^{7}$ Infrared Ray has a therapeutic effect of increasing the blood supply and relieving the Pain. This will increase the supply of oxygen and nutrient available to the tissues, accelerate the removal of the waste products and help to bring out the resolution of

'Financial or Other Competing Interest': None.

Submission 10-07-2017, Peer Review 12-12-2017,

Acceptance 18-12-2017, Published 01-01-2018.

Corresponding Author:

Dr. Mariappan Gomathi,

Associate Professor

Government Vellore Medical College Hospital,

Adukkamparai, Vellore-632011.

E-mail: sureshgomes@yahoo.com

DOI: $10.14260 /$ jemds/2018/23

\section{(c) $(i)(5)$}

inflammation. When the heat is mild, the relief of pain is probably due to the sedative effect on the superficial sensory nerve endings. It also helps to achieve muscular relaxation and relief of muscle spasm associated with injury or inflammation. Heat transmission with IR radiation is governed by inverse square law, it states that the intensity of radiation varies inversely with the square of the distance between the source of radiation and the skin. Intensity of the radiation is reduced if the distance between the source and the target is increased and vice versa. The duration of the exposure should be 15 to 20 minutes once or twice a day. The treatment commences with the IR source placed at distance of 30 " to 36 " from the surface being treated.8,9,10 When the heat is mild, the relief of pain is probably due to the sedative effect on the superficial sensory nerve endings. It is also helping achieve muscular relaxation and for the relief of muscle spasm associated with injury or inflammation. ${ }^{11,12,13}$ Infrared rays also have the physiological effect on cutaneous vasodilation due to liberation of chemical vasodilators, histamine and similar substance, as well as possible direct effect on the blood vessels. 


\section{Effect of IRR}

1. Relief of pain due to sedative effect on superficial sensory nerve ${ }^{7}$ endings.

2. Relieving muscle spasm. ${ }^{6}$

3. Increases the blood circulation. ${ }^{6}$

\section{Contraindication for IRR}

1. Pacemaker/Defibrillator in situ. ${ }^{7}$

2. Open injury.

3. Impaired arterial blood supply.

4. Impaired skin sensation.

5. Pregnancy.

6. Fever.

7. Bleeding disorders. ${ }^{14}$

\section{Complication of IRR}

1. Superficial heat burns.

2. Electrical shock.

3. Gangrene.

4. Headache.

\section{Episiotomy}

Episiotomy is a surgically planned incision on the perineum and posterior vaginal wall done during second stage of labour. Pain following episiotomy appears to be universal. Various interventions are found to aid the pain relief process which includes, cleanliness, applying ice pack, IRR, sitz baths. IRR was found very effective in pain relief. Thus, the present study was planned to evaluate the effectiveness of IRR therapy on pain relief of episiotomy wound among postnatal mothers.

\section{MATERIALS AND METHODS}

The non-randomised controlled trial was carried out in the Obstetrics and Gynaecology, Madras Medical College, Chennai. All the postnatal mothers aged between 18-34 years who underwent right or left mediolateral episiotomy admitted in postnatal ward were considered. Ethical clearance was obtained from institutional ethics committee and written consent was taken from all subjects. According to Visual Analogue Score (VAS score) in controlled group was $0.08 \pm 0.4$ and in experimental group was $0.04 \pm 0.2$ at $5 \%$ level of significance and $80 \%$ power. The minimum number of postnatal mothers are required to be studied in each of control group and experimental group. The final calculated sample size was 460 (230 in each group). The participants were assigned to the treatment groups (experimental and control groups) by using haphazard allocation by alternation. Everyday twenty postnatal mothers were selected after taking consent the socio-demographic data were collected by using structured interview schedule and episiotomy wound was assessed by REEDA SCALE and visual analogue score. REEDA SCALE indicates Redness, Oedema, Ecchymosis, Discharge, Approximation and total score ranges between 0 and 15.0 to 2 - Good, 3 to 5 - Moderate, 6 to 8 - Mild and 9 to 15 - Poor. After taking written consent, routine perineal care was given to both experimental and control group, the infrared lamp therapy was given only to experimental group twice a day, morning and evening. The procedure continued for 3 days. Episiotomy wound pain relief assessment was done on each day morning and evening up to $4^{\text {th }}$ day morning for both experimental and control groups; first day before therapy considered for pre-assessment and $4^{\text {th }}$ day morning was the post-assessment.

\begin{tabular}{|c|c|c|c|c|}
\hline & \multicolumn{2}{|c|}{ Pre-Treatment } & \multicolumn{2}{c|}{ Post-Treatment } \\
\hline & $\begin{array}{c}\text { Control } \\
\text { Group }\end{array}$ & $\begin{array}{c}\text { Experimental } \\
\text { Group }\end{array}$ & $\begin{array}{c}\text { Control } \\
\text { Group }\end{array}$ & $\begin{array}{c}\text { Experi- } \\
\text { mental } \\
\text { Group }\end{array}$ \\
\hline Good & $0(0.00)$ & $0(0.00)$ & $0(0.00)$ & $214(92.64)$ \\
\hline Moderate & $\begin{array}{c}14 \\
(6.00)\end{array}$ & $\begin{array}{c}12 \\
(5.19)\end{array}$ & $\begin{array}{c}136 \\
(58.37)\end{array}$ & $\begin{array}{c}17 \\
(7.36)\end{array}$ \\
\hline Mild & $8(3.44)$ & $10(4.33)$ & $84(36.05)$ & $0(0.00)$ \\
\hline Poor & $\begin{array}{c}211 \\
(90.56)\end{array}$ & $\begin{array}{c}209 \\
(90.48)\end{array}$ & $\begin{array}{c}13 \\
(5.58)\end{array}$ & $\begin{array}{c}0 \\
(0.00)\end{array}$ \\
\hline Table 1. Comparison between Post-Treatment Score of \\
Experimental Group and Control Group \\
\hline
\end{tabular}

Pre-treatment wound score in experimental group and control group was similar $(\mathrm{t}=1.375, \mathrm{p}=0.174)$. In comparison to pre-treatment score, there was significant reduction in post-treatment score in both experimental and control groups. However, comparison between post-treatment score of experimental and control group revealed that there was significant reduction in the score of experimental group.

The tool measuring socio-demographic factors was validated by the expert's reliability of tool. It was established using Karl Pearson's correlation coefficient formula and it was 0.9454 . The Visual Analogue score as the name implies uses an analogue format meaning that it represents a continuous range of values. The most common style used in pain management uses a horizontal line measuring exactly 10 $\mathrm{cm}$ (100 millimetres). The patient is asked to make a mark on this line, then the line is measured and recorded in millimetres or centimetres.

The length of the line is important for this outcome measure since this tool has been evaluated in this format and the measurement relies on the line being exactly $10 \mathrm{~cm}$ long. Therefore, VAS as a paper measure, photocopying needs to be monitored since this process may alter the length of the scale and invalidate the instrument.

\section{Statistical Analysis}

Qualitative data was summarised into count and percentages and Quantitative data into mean and standard deviation. Comparison of qualitative variables, between experimental group and control group was done by Chi-square test While of Quantitative variables was by ' $t$ ' test. The comparison was set to be significant if $\mathrm{p}$ was less than 0.05. Epi Info Version 6 software was used.

\section{RESULTS}

The experimental group consisted of 230 postnatal mothers and control group had 230 postnatal mothers. Postnatal mothers in both experimental groups and controlled groups, were similar in the following aspects: age, parity, analgesics use, antibiotics use and perineal care. All mothers were para 1. This indicates characteristics of experimental and control group were matching with each other and demonstrated statistically significant homogeneity in all the characteristics. According to VAS score, in pre-treatment assessment, more than $90 \%$ subjects of both control as well as experimental group were in poor category $\left(\mathrm{X}^{2}=0.3770, \mathrm{p}=0.8282\right)$, no one was good. However, VAS analysis of post-exposure revealed that significantly high proportion of postnatal mothers 
(92.64\%) were having good pain relief while no one from control group was having good relief. Comparison between post-treatment scores of experimental and control group revealed that there was significant reduction in the score of experimental group.

\begin{tabular}{|c|c|c|c|c|c|}
\hline & & Control & $\%$ & Experimental & $\%$ \\
\hline \multirow{3}{*}{ Age } & $18-21$ & 69 & $30.10 \%$ & 66 & $28.30 \%$ \\
\hline & $22-25$ & 85 & $36.90 \%$ & 92 & $40.00 \%$ \\
\hline & $26-34$ & 76 & $33.00 \%$ & 127 & $31.70 \%$ \\
\hline \multirow{3}{*}{ Educational level } & Primary & 44 & $19.30 \%$ & 41 & $18.10 \%$ \\
\hline & Secondary & 148 & $64.00 \%$ & 149 & $65.30 \%$ \\
\hline & Graduate & 39 & $16.70 \%$ & 38 & $16.60 \%$ \\
\hline \multirow{2}{*}{ Parity } & Primi & 212 & $92.00 \%$ & 214 & $93.00 \%$ \\
\hline & Multi & 19 & $8.00 \%$ & 17 & $7.00 \%$ \\
\hline \multirow{2}{*}{ Previous LSCS } & Yes & 02 & 0.87 & 03 & $1.30 \%$ \\
\hline & No & 228 & 99.13 & 227 & 98.70 \\
\hline \multirow{2}{*}{ Antibiotics } & Oral & 230 & 100 & 230 & 100 \\
\hline & IV & & & & \\
\hline \multirow{2}{*}{ Analgesics } & Oral & 230 & 100 & 230 & 100 \\
\hline & IV & & & & \\
\hline \multirow{2}{*}{ Occupation } & House wife & 155 & $67.00 \%$ & 157 & $68.00 \%$ \\
\hline & Working & 78 & $33.00 \%$ & 74 & $32.00 \%$ \\
\hline \multicolumn{6}{|c|}{ Table 2. Demographic Characteristics of Experimental and Control Groups } \\
\hline
\end{tabular}

\begin{tabular}{|c|c|c|c|}
\hline Group & $\begin{array}{c}\text { Pre } \\
\text { Treatment } \\
\text { Mean } \pm \text { SD }\end{array}$ & $\begin{array}{c}\text { Post } \\
\text { Treatment } \\
\text { Mean } \pm \text { SD }\end{array}$ & $\begin{array}{c}\text { Paired 't' } \\
\text { test value }\end{array}$ \\
\hline Experimental & $14.81 \pm 0.91$ & $0.91 \pm 0.92$ & $51.973^{* *}$ \\
\hline Control & $14.92 \pm 0.81$ & $5.73 \pm 1.32$ & $107.912^{* *}$ \\
\hline $\begin{array}{c}\text { Unpaired ' } \mathrm{t} \text { ' } \\
\text { test value }\end{array}$ & 1.375 & $45.440^{* *}$ & \\
\hline
\end{tabular}

Table 3. Pre- and Post-Treatment Scores on Episiotomy Wound Healing of Experimental and Control Group

$* *: \mathrm{p}<0.001$

\begin{tabular}{|c|c|c|c|c|}
\hline \multirow{2}{*}{$\begin{array}{c}\text { VAS } \\
\text { Score }\end{array}$} & \multicolumn{2}{|c|}{ First Day } & \multicolumn{2}{|c|}{ Fourth Day } \\
\hline & $\begin{array}{c}\text { Control } \\
\text { Group }\end{array}$ & $\begin{array}{c}\text { Experimental } \\
\text { Group }\end{array}$ & $\begin{array}{l}\text { Control } \\
\text { Group }\end{array}$ & $\begin{array}{l}\text { Experimental } \\
\text { Group }\end{array}$ \\
\hline $\begin{array}{c}\text { No Pain } \\
(0-4)\end{array}$ & - & - & 20 & 90 \\
\hline $\begin{array}{c}\text { Moderat } \\
\text { e Pain } \\
(5-9)\end{array}$ & - & - & 130 & 138 \\
\hline $\begin{array}{l}\text { Worst } \\
\text { Pain } \\
(10)\end{array}$ & 230 & 230 & 80 & 2 \\
\hline
\end{tabular}

Table 4. VAS score Categories of Postnatal Mothers

$* *: \mathrm{p}<0.001$

Pre and post-treatment score on Episiotomy wound pain relief of experimental and control group.

\section{DISCUSSION}

In the present study, all socio-demographic variables and pretreatment REEDA score of experimental and control groups were similar. Post-treatment comparison revealed significantly good wound healing in experimental group as compared to control group. This indicates that the improvement in pain relief in experimental group may be due to infrared lamp therapy. Episiotomy wound pain relief is good after infrared lamp therapy.

\section{CONCLUSION}

The study result showed that infrared light application was effective in enhancing wound healing and relieving pain level among the postnatal mothers. All the subjects in the experimental group had reduced pain level. This is also the cheapest procedure and convenient measure. So this infrared light therapy can be administered as an adjunct therapy by health personnel in their day-to-day caring of the mother in hospital setting. It is concluded that Infrared lamp radiation therapy is an effective modality of treatment for pain relief of episiotomy wound.

\section{REFERENCES}

[1] Dutta DC. Text book of obstetrics including perinatology and contraception. $6^{\text {th }}$ edn.Calcutta: New Central Book Agency 2004.

[2] Zainur RZ, Loh KY. Postpartum morbidity--what we can do. Med J Malaysia 2006;61(5):651-6.

[3] Fraser DM, Cooper MA. Myles text book for midwives. 14th edn. Philadelphia: Churchill Livingstone 2003.

[4] Thacker SB, Banta HD. Benefits and risks of episiotomy: an interpretative review of the English language literature, 1860-1980. ObstetGynecolSurv 1983;38(6):322-38.

[5] World Health Organization Report. Life in the $21^{\text {st }}$ century: a vision for all. 1998.

[6] Baruha B, Raddi SA.A study to assess the effect of infrared radiation (Lamp) in episiotomy wound healing among post natal mothers. J S A FOG 2010:236-8.

[7] Nam HK, Park YS. A study on comparisons of ice bag and heat lamp for the relief of perineal discomfort. KanhoHakhoe Chi 1991;21(1):27-40.

[8] Biswas C. A comparative study to assess the effectiveness of infrared radiation on episiotomy wound healing in selected hospitals, west Bengal. 2009.

[9] Campbell WG. Form and style in the thesis writing. $2^{\text {nd }}$ edn. Boston, MA: HongtonMiffin Company,1978:11328. 
[10] Dutta DC. Text book of gynaecology. $6^{\text {th }}$ edn. Calcutta: New Central Book Agency Pvt Ltd.,2005:588-97.

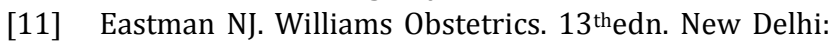
Churchill Livingstone1950: p. 23.

[12] Ezechi OC, Edet A, Akinlade H, et al. Incidence and risk factors for caesarean wound infection in Lagos Nigeria. BMCRes Notes2009;2:186.
[13] Danso KA, Adu-Sarkodie Y. Abdominal wound infection complicating caesarean section. Ghana Medical Journal 1998;32b:1003-8.

[14] Maksin JKV.The treatment of wounds of the anal canal and perineum. J Clin Laser Med Surg 2004;8:20-2. 